\title{
PENGEMBANGAN VIDEO PEMBELAJARAN DODOT PENGANTIN PUTERI GAYA SOLO BASAHAN
}

\author{
Eni Juniastuti,Yuswati dan Asi Tritanti \\ Prodi Tata Rias dan Kecantikan, Jurusan Pendidikan Teknik Boga dan Busana, Fakultas Teknik, \\ Universitas Negeri Yogyakarta \\ Email: enijuniastuti@uny.ac.id
}

\begin{abstract}
Tujuan dari penelitian ini adalah: 1) untuk mengembangkan naskah program video pembelajaran Dodot Pengantin Putri Gaya Solo Basahan, 2) untuk menguji kelayakan video pembelajaran Dodot Pengantin Putri Gaya Solo Basahan. Penelitian ini merupakan penelitian pengembangan (research and development). Subyek penelitian adalah mahasiswa semester 3 dan semester 5 prodi D3 Tata Rias dan kecantikan FT UNY tahun angkatan 2008 yang sudah mengambil Mata Kuliah Pengantin Indonesia II dan angkatan 2009 yang belum mengambil Mata Kuliah Pengantin Indonesia II. Data penelitian dianalisis dengan teknik deskriptif kuantitatif secara sederhana, yakni dengan membandingkan nilai rerata. Hasil penelitian menunjukkan bahwa: 1) Pengembangan Video Pembelajara Dodot pengantin gaya solo basahan terdiri dari beberapa tahapan antara lain: a)Terdapat perencanaan dalam merumuskan tujuan, disesuaikan dengan kebutuhan mahasiswa agar dapat tercapai kompetensi dibidang Tata Rias Pengantin.b) Pembuatan produk Video Pembelajara Dodot pengantin gaya Solo Basahan dengan prosedur yang direncanakan.c) Uji coba Video untuk memvalidasi produk, dengan validasi ahli materi,dan ahli media yang berkompeten di bidang Tata Rias Pengantin Terutama penganti Gaya Solo Basahan . d) Merevisi hasil produk dan memperbaiki sebelum dilakukan uji coba dilapangan.e) Uji coba produk dilapangan atau pada pengguna produk tersebut.f) membuat laporan hasil sesuai dengan data yang diperoleh dilapangan baik dari ahli materi, ahli media dan pengguna Video Dodot pengantin gaya Solo Basahan 2) penelitian Video Pembelajaran Dodot Pengantin Putri Gaya Solo Basahan Puteri ini dalam kategori sangat layak sebagai sumber belajar menurut ahli media dan ahli materi, dan baik berdasarkan hasil uji coba di lapangan.
\end{abstract}

Kata Kunci: video pembelajaran, dodot pengantin puteri gaya solo basahan

\section{PENDAHULUAN}

Garis besar Kurikulum D III Tata Rias dan Kecantikan Fakultas Teknik Universitas Negeri Yogyakarta, bertujuan mengembangkan 4 kompetensi utama yaitu mencetak tenaga professional dibidang Tata Rias, Tata Kecantikan Rambut, Perawatan Kecantikan dan Tata Rias Pengantin. Kompetensi Tata Rias Pengantin dibagi menjadi Tata Rias Pengantin Indonesia, Tata Rias Pengantin Barat dan Tata Rias Pengantin Muslim. Indonesia memiliki beragam suku dan tata upacara adat serta Tata Rias Pengantin yang memiliki kekhasan masing-masing diberbagai daerah diseluruh Indonesia.

Berpijak pada kearifan lokal dan muatan lokal, maka Prodi Tata Rias dan Kecantikan FT UNY secara khusus menekankan pengembangan kompetensi Rias Pengantin Yogyakarta dan Surakarta, disamping Gaya Tata Rias lainnya diseluruh
Indonesia. Tata Rias Pengantin Yogyakarta dan Surakarta memiliki ciri khas yang unik dan tingkat kesulitan yang sangat tinggi, baik dalam Merias Wajah (Paes/cengkorongan), penataan sanggul, busana maupun asesoriesnya. Gaya Tata Rias Pengantin Surakarta terdiri dari Tata Rias Pengantin Gaya Solo Puteri dan Tata Rias Pengantin Gaya Solo Basahan. Kedua Gaya Tata Rias tersebut yang memiliki tingkat kesulitan paling tinggi adalah Gaya Solo Basahan, khususnya dalam mengenakan Busananya yang berbentuk Dodot (yang dibuat dari kain panjang).

Proses belajar mengajar materi mengenakan Dodot, dirasakan kesulitan baik bagi pengajar maupun bagi mahasiswa, karena mahasiswa harus dibimbing satu persatu dan tahap demi tahap. Berbagai upaya telah dilakukan para dosen pengampu dalam menjelaskan tahapan mengenakan Dodot, baik secara teori maupun demonstrasi, namun masih saja terjadi 
masalah dalam mencapat unjuk kerja mahasiswanya, hingga latihanpun berlangsung sangat lama. Sehingga tidak mengherankan bila pada praktek mengenakan Dodot ini, sering terjadi mahasiswa pingsan karena kelelahan. Media lain selain Demonstrasi adalah Foto/ Chart yang berisi tentang tahapan mengenakan Dodot Solo Basahan ini, namun dalam prakteknya mahasiswa tetap mendapatkan kesulitan. Materi mengenakan Dodot ini, merupakan sebagian kecil dari bahan ajar Tata Rias Pengantin Gaya Solo Basahan.

Media sebagai alat bantu proses belajar mengajar dimanfaatkan oleh dosen atau guru dalam proses pembelajaran. Setiap jenis media memiliki karakteristik dan kemampuan dalam menayangkan pesan dan informasi (Kemp, 1995). Karakteristik dan kemampuan masing-masing media perlu diperhatikan oleh para pengajar agar mereka dapat memilih media yang tepat dengan kondisi dan kebutuhan. Pemilihan dan pemanfaatan media dapat disesuaikan dengan kondisi yang dihadapi. Media adalah segala bentuk dan saluran yang digunakan untuk menyampaikan pesan atau informasi. Menurut Schramm (Miarso, 1986) memberikan pengertian media adalah "Information carrying technologies that can be used for intruction. The media of intruction, consequently are extensions of the reacher". Inti dari pendapat Schramm adalah bentuk teknologi yang dapat berguna dalam pemberian informasi untuk disebarkan kesemua sehingga semua orang mendapatkan informasi dan pengetahuan.

Menurut Naniek Saryoto (2008) Busana Pengantin Solo memiliki 2 gaya, yaitu Gaya Solo Puteri dan Gaya Solo Basahan. Busana Pengantin Wanita. Pada pengantin wanita Solo Basahan mengenakan kain Cinde Kembang atau Cinde Cakar Tanpa Seret warna merah atau disesuaikan dengan warna dodot (kampuh), Sangkelat, stagen, longtorso, Udet dari bahan cinde, Januran dan Slepe (bathokan), Buntal Udan Mas. Dodot (kampuh) yang dipergunakan untuk pengantin wanita corak alas-alas pradan. Buntal merupakan rangkaian hiasan bunga bawang sebungkul yang panjangnya sekitar $140 \mathrm{~cm}$ dipasang di pinggang pengantin wanita.
Busana Solo Basahan berupa dodot atau kampuh dengan pola batik warna gelap bermotif alas-alasan (binatang) dan tetumbuhan hutan. Seiring berjalannya waktu, pilihan motif dan corak warna dodot semakin beragam namun pilihan motif batik kain dodot tetap berpegang pada filosofi derajat mulia yang layak dikenakan pasangan pengantin.

Oleh karenanya, perlu diupayakan pengembangan media lain yang tepat untuk pembelajaran materi tersebut, salah satunya adalah dengan mengembangkan program Video pembelajaran mengenakan Dodot Gaya Solo Basahan. Berbagai media CD/ DVD telah diperjual belikan dipasaran, namun sejauh ini belum menemukan Video pembelajaran mengenakan Dodot Gaya Solo Basahan . Rumusan masalah dalam penelitian pengembangan ini adalah: (1) Bagaimana naskah video pembelajaran Dodot Pengantin Putri Gaya Solo Basahan. (2) Bagaimana kelayakan video pembelajaran Dodot Pengantin Putri Gaya Solo Basahan.

\section{METODE} merupakan metode penelitian pengembangan yang dikenal dengan nama Research and development yaitu penelitian yang menghasilkan produk tertentu dan menguji kelayakan produk. Adapun produk yang dihasilkan yaitu video pembelajaran dodot pengantin putrid gaya Solo Basahan.

Penelitian ini mengunakan model pengembangan Borg dan Gall (1983: 276277), yang bertujuan untuk mengembangkan dan menvalidasi produk pendidikan dan pembelajaran untuk meningkatkan mutu dan pembelajaran efektif, interaktif dan adaptable. Subyek penelitian tindakan kelas ini mahasiswa semester 3 dan semester 5 prodi D3 Tata Rias dan kecantikan FT UNY tahun angkatan 2008 yang sudah mengambil Mata Kuliah Pengantin Indonesia II dan angkatan 2009 yang belum mengambil Mata Kuliah Pengantin Indonesia II.

Instrumen dan Pengumpulan data yang diterapkan dalam penelitian ini yaitu sebagai berikut Pengamatan partisipatif, Obsevasi Lapangan, Pemanfaatan dan analisis data dokumen II, Penelitian 
Lapangan dan Uji praktik Keterampilan Pemakaian Dodot setelah melihat tayangan video dan diaplikasikan pada praktik pemakaian ke model pengantin pada saat uji coba awal sampai uji coba akhir.

Teknik analisis data yang digunakan dalam penelitian ini deskriptif kualitatif.teknik digunakan untuk mengolah data yang bersifat kualitatif. Data kualitatif berupa data perilaku mahasiswa yang menunjukan berbagai aktivitas dan adanya interaksi dalam pembelajaran.Adapun data yang bersifat kuantitatif secara sederhana, seperti hasil nilai pemakaian dodot sebelum maupun sesudah tindakan akan dianalisis dengan teknik deskriptif kuantitatif secara sederhana, yakni dengan membandingkan nilai rerata

\section{HASIL DAN PEMBAHASAN}

Data Validasi Ahli Materi diperoleh dengan cara memberikan angket yang mencakup aspek pembelajaran dan aspek isi. Ahli materi menggunakan produk video pembelajaran Dodot Pengantin Putri Gaya Solo Basahan didampingi oleh peneliti. Validasi produk video pembelajaran dilakukan pada tanggal 21 Oktober oleh Ibu Elok Novita, S.Pd. Masukan yang diberikan digunakan untuk langkah revisi. Adapun hasil validasi pada aspek pembelajaran dan aspek isi oleh ahli materi dapat digambarkan sebagai berikut:

Tabel 1

Skor Penilaian Aspek Pembelajaran oleh Ahli Materi

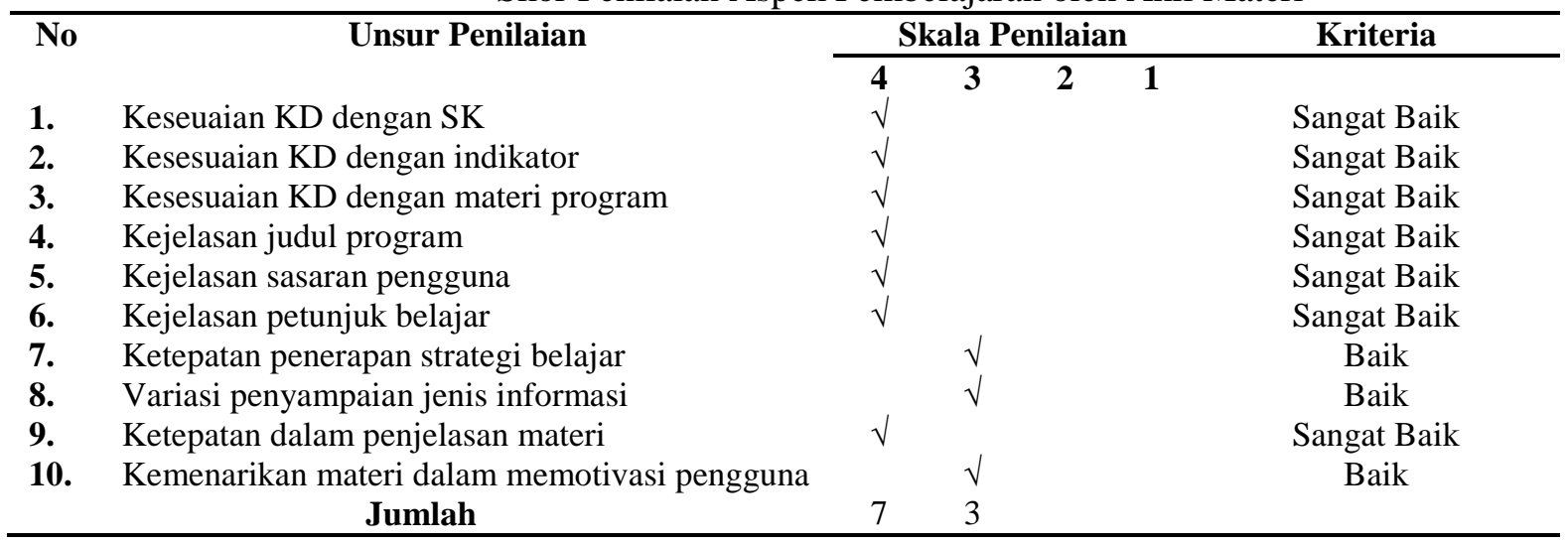

Berdasarkan Tabel 1 di atas, hasil data yang diperoleh dari penilaian pada aspek pembelajaran oleh ahli materi menunjukkan bahwa skala penilaian 4 sebanyak 7 dan skala penilaian 3 sebanyak 3 . Penilaian ini menunjukkan bahwa skala penilaian 4 lebih sering tampak dari skala penilaian yang lain. Skala penilaian 4 menyatakan sangat baik dan hal ini berarti dari aspek pembelajaran pada produk penelitian ini dapat dikatakan sangat baik. Jadi dapat disimpulkan bahwa sudah sangat baik dan sesuai dengan dalam aspek pembelajaran dan dapat digunakan pada pembelajaran

Aspek isi dimaksudkan untuk mengetahui bagaimudah sana penilaian ahli materi mengenai berbagai macam hal yang menyangkut isi/materi dari produk video pembelajaran. Peneliti akan mengetahui perlu tidaknya revisi pada produk dengan pedoman penilaian ini. Hasil penilaian tersebut dapat dilihat pada Tabel berikut:

Tabel 3.

Skor Penilaian Aspek Isi oleh Ahli Materi

\begin{tabular}{llllll}
\hline No & & Unsur Penilaian & \multicolumn{2}{c}{ Skala Penilaian } & \multirow{2}{*}{ Kriteria } \\
\cline { 3 - 5 } & & $\mathbf{4}$ & $\mathbf{3}$ & $\mathbf{2}$ & $\mathbf{1}$ \\
\\
\cline { 3 - 5 } $\mathbf{1 .}$ & Cakupan isi materi & $\sqrt{ }$ & & Sangat Baik \\
2. & Kejelasan isi materi & $\sqrt{ }$ & & Sangat Baik \\
3. & Urutan isi materi & $\sqrt{ }$ & & Sangat Baik \\
\hline
\end{tabular}




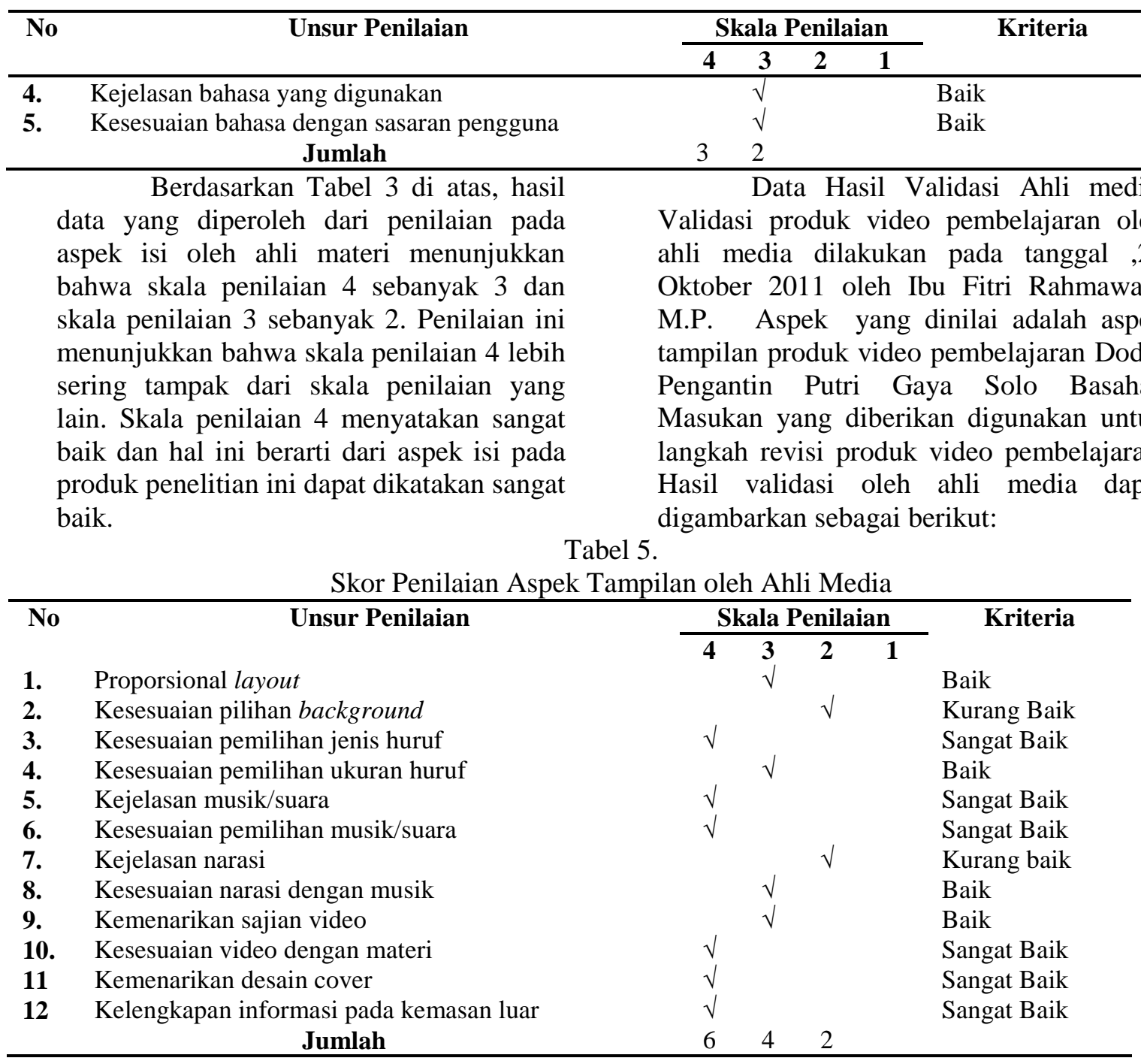

Berdasarkan Tabel 5 di atas, hasil data yang diperoleh dari penilaian pada aspek tampilan oleh ahli media menunjukkan bahwa skala penilaian 4 sebanyak 6 dan skala penilaian 3 sebanyak 4, dan skala penilaian 2 sebanyak 2. Penilaian ini menunjukkan bahwa skala penilaian 4 lebih sering tampak dari skala penilaian yang lain. Skala penilaian 4 menyatakan sangat baik dan hal ini berarti dari aspek tampilan pada produk penelitian ini dapat dikatakan sangat baik.

Data hasil uji coba pengguna diperoleh dengan cara memberikan angket yang mencakup tentang aspek tampilan produk video pembelajara, aspek kemudahan produk untuk dipelajari isinya, dan aspk audio pada produk video pembelajaran dodot pengantin putri gaya Solo Basahan. Sebanyak 24 orang mahasiswa diminta sebagai subyek penelitian, mencoba menggunakan produk video pembelajaran ini didampingi oleh pengembang. Mahasiswa dapat menanyakan langsung tentang hal-hal yang berkaitan dengan produk yang dikembangkan dan memberikan masukan berupa kritik dan saran kepada pengembang yang nantinya akan digunakan sebagai pedoman untuk melakukan revesi.

a. Data yang berkenaan dengan aspek tampilan video pembelajaran

Aspek tampilan video pembelajaran terdiri dari delapan butir pernyataan. Skor penilaian yang diberikan oleh mahasiswa akan digunakan untuk menentukan apakah kualitas tampilan produk video pembelajaran sangat baik, baik, cukup baikatau kurang baik. Hasil penilaian tersebut dapat dilihat pada table 6 sebagai berikut: 
Skor Penilaian Aspek Tampilan Produk oleh Pengguna

\begin{tabular}{|c|c|c|c|c|c|c|c|c|c|c|c|c|c|c|c|c|c|c|c|c|c|c|c|c|}
\hline \multirow[t]{2}{*}{ No } & \multirow[t]{2}{*}{ Pernyataan } & \multicolumn{23}{|c|}{ Mahasiswa } \\
\hline & & $\overline{\mathrm{A} \mathrm{B}}$ & $\begin{array}{ll}\mathrm{C} \\
\end{array}$ & $\mathrm{D}$ & $E$ & F & $\bar{G}$ & $\mathrm{H}$ & I & $\bar{J}$ & $\mathrm{~K}$ & $\mathrm{~L}$ & $\bar{M}$ & $\bar{N}$ & $\mathrm{O}$ & $\overline{\mathrm{P}}$ & $\mathrm{Q}$ & $\overline{\mathrm{R}}$ & $\mathrm{S}$ & $\mathrm{T}$ & $\bar{U}$ & $\mathrm{~V}$ & $\mathrm{~W}$ & $\mathrm{X}$ \\
\hline 1 & $\begin{array}{l}\text { Tayangan } \\
\text { pembuka } \\
\text { sesuai } \\
\text { dengan } \\
\text { Judul } \\
\text { program }\end{array}$ & 33 & $\begin{array}{ll}33 \\
\end{array}$ & 4 & 4 & 3 & 3 & 3 & 3 & 3 & 3 & 3 & 3 & 3 & 3 & 4 & 3 & 3 & 3 & 3 & 3 & 3 & 3 & 3 \\
\hline 2 & $\begin{array}{l}\text { Kualitas } \\
\text { tampilan } \\
\text { gambar baik }\end{array}$ & 22 & 22 & 4 & 4 & 3 & 3 & 3 & 3 & 3 & 3 & 3 & 3 & 3 & 3 & 3 & 3 & 3 & 3 & 1 & 3 & 3 & 3 & 3 \\
\hline 3 & $\begin{array}{l}\text { Pemilihan } \\
\text { lokasi// } \\
\text { tempat } \\
\text { sesuai }\end{array}$ & 22 & 22 & 1 & 1 & 3 & 3 & 3 & 2 & 2 & 2 & 2 & 1 & 1 & 3 & 2 & 3 & 2 & 2 & 1 & 2 & 2 & 2 & 2 \\
\hline 4 & $\begin{array}{l}\text { Pemilihan } \\
\text { model sesuai }\end{array}$ & 33 & 33 & 4 & 4 & 3 & 3 & 3 & 3 & 3 & 3 & 3 & 3 & 3 & 4 & 3 & 4 & 3 & 3 & 4 & 3 & 3 & 3 & 4 \\
\hline 5 & $\begin{array}{l}\text { Pemilihan } \\
\text { pendemo } \\
\text { sesuai }\end{array}$ & 33 & 33 & 4 & 4 & 3 & 3 & 3 & 3 & 3 & 3 & 3 & 3 & 3 & 3 & 3 & 3 & 3 & 3 & 2 & 3 & 3 & 3 & 4 \\
\hline 6 & $\begin{array}{l}\text { Kualitas } \\
\text { pencahayaan } \\
\text { baik }\end{array}$ & 33 & 32 & 4 & 4 & 3 & 3 & 3 & 4 & 3 & 3 & 3 & 3 & 3 & 3 & 3 & 3 & 3 & 3 & 1 & 3 & 3 & 3 & 3 \\
\hline 7 & $\begin{array}{l}\text { Teks mudah } \\
\text { dibaca }\end{array}$ & 4 & 43 & 4 & 4 & 3 & 3 & 3 & 3 & 4 & 4 & 4 & 3 & 4 & 3 & 4 & 3 & 4 & 4 & 3 & 4 & 3 & 3 & 2 \\
\hline 8 & $\begin{array}{l}\text { Pemilihan } \\
\text { Font sesuai }\end{array}$ & 44 & 43 & 4 & 4 & 3 & 3 & 3 & 3 & 3 & 3 & 3 & 3 & 3 & 3 & 4 & 3 & 3 & 3 & 3 & 3 & 3 & 3 & 2 \\
\hline $\begin{array}{l}\text { yar } \\
\text { pad } \\
\text { per } \\
\text { per } \\
\text { per } \\
\text { seb } \\
\text { Per } \\
\text { per } \\
\text { per } \\
\text { me }\end{array}$ & $\begin{array}{l}\text { Berdasarkan } \\
\text { g diperoleh da } \\
\text { a aspek } \\
\text { lbelajaran m } \\
\text { ilaian } 4 \text { mur } \\
\text { ilaian } 3 \text { seban } \\
\text { anyak } 21 \text {, dan } \\
\text { ilaian ini n } \\
\text { ilaian } 3 \text { lebih } \\
\text { ilaian yang } \\
\text { lyatakan baik } \\
\text { pilan produk d }\end{array}$ & $\begin{array}{l}\text { Tabe } \\
\text { ari pe } \\
\text { tamp } \\
\text { enun } \\
\text { tcul } \\
\text { nyak } \\
\text { skala } \\
\text { nenur } \\
\text { ser } \\
\text { lain } \\
\text { dan } \\
\text { lapat }\end{array}$ & $\begin{array}{l}\text { el } 6 \\
\text { enilai } \\
\text { pilan } \\
\text { njukk } \\
\text { seba } \\
130 \text {, } \\
\text { a peni } \\
\text { Injukk } \\
\text { ring } \\
\text { t. Sk } \\
\text { hal in } \\
\text { dikat }\end{array}$ & $\begin{array}{l}\text { di at } \\
\text { an o } \\
\text { pr } \\
\text { an } \\
\text { anyak } \\
\text { ska } \\
\text { laian } \\
\text { kan } \\
\text { tamp } \\
\text { kala } \\
\text { ii ber } \\
\text { takan }\end{array}$ & $\begin{array}{l}\text { as, } \\
\text { eh I } \\
\text { odu } \\
\text { bah } \\
3 \\
\text { la p } \\
1 \text { s } \\
\text { bah } \\
\text { ak } \\
\text { pe } \\
\text { arti } \\
\text { bai }\end{array}$ & $\begin{array}{l}\text { has } \\
\text { mah } \\
\mathrm{k} \\
\text { wa } \\
\text { 4, } \\
\text { enil } \\
\text { ebar } \\
\text { wa } \\
\text { dari } \\
\text { nila } \\
\text { dari } \\
\text { k. }\end{array}$ & $\begin{array}{r}\text { il } \\
\text { asi } \\
\text { vi } \\
\mathrm{s} \\
\mathrm{s} \\
\text { aia } \\
\text { hya } \\
\mathrm{s} \\
\mathrm{s}\end{array}$ & la & & & & & $\begin{array}{l}\text { lipel } \\
\text { erny } \\
\text { leh } \\
\text { nene } \\
\text { semb } \\
\text { siny } \\
\text { nuda } \\
\text { lipel } \\
\text { lapa }\end{array}$ & e & t & $\begin{array}{l}\text { be } \\
\text { rodı } \\
\text { ek k } \\
\text { nya } \\
\text { Skor } \\
\text { sswa } \\
\text { a } \\
\text { ah } \\
\text { lajar } \\
\text { nya }\end{array}$ & $\begin{array}{l}\text { ren } \\
\text { lk ut } \\
\text { emt } \\
\text { terd } \\
\text { per } \\
\text { ak } \\
\text { pak } \\
\text { anga } \\
\text { dipe } \\
\text { i isi } \\
\text { Ha } \\
\text { la ta }\end{array}$ & $\begin{array}{l}\text { laan } \\
\text { ntuk } \\
\text { udah } \\
\text { iri d } \\
\text { illai } \\
\text { can } \\
\text { ah } \\
\text { at } \\
\text { elaja } \\
\text { inya } \\
\text { asil } \\
\text { bel. }\end{array}$ & $\begin{array}{l}\text { d } \\
\text { dip } \\
\text { tan } \\
\text { lari } \\
\text { an y } \\
\text { digi } \\
\text { pr } \\
\text { mud } \\
\text { Iri } \\
\text { ata } \\
\text { peni } \\
7 \text { st }\end{array}$ & $\begin{array}{l}\text { eng } \\
\text { elaj } \\
\text { proc } \\
\text { sem } \\
\text { rang } \\
\text { unak } \\
\text { odu } \\
\text { lah } \\
\text { ising } \\
\text { au s } \\
\text { ilaia } \\
\text { ebay }\end{array}$ & $\begin{array}{l}\text { an } \\
\text { ari i } \\
\text { duk } \\
\text { bila } \\
\text { dib } \\
\text { kan } \\
\text { k } \\
\text { dip } \\
\text { ya, } \\
\text { ulit } \\
\text { in te } \\
\text { gai b }\end{array}$ & $\begin{array}{l}\text { asp } \\
\text { isiny } \\
\text { unt } \\
\text { n bu } \\
\text { erik } \\
\text { unt } \\
\text { vid } \\
\text { belaj } \\
\text { cuk } \\
\text { unt } \\
\text { ersel } \\
\text { beril }\end{array}$ & $\begin{array}{l}\text { Dek } \\
\text { ya } \\
\text { tuk } \\
\text { utir } \\
\text { kan } \\
\text { tuk } \\
\text { deo } \\
\text { jari } \\
\text { xup } \\
\text { tuk } \\
\text { but } \\
\text { kut }\end{array}$ & \\
\hline
\end{tabular}

Tabel 7

Skor Penilaian Aspek Kemudahan Produk Untuk Dipelajari Isinya

\begin{tabular}{|c|c|c|c|c|c|c|c|c|c|c|c|c|c|c|c|c|c|c|c|c|c|c|c|c|c|}
\hline \multirow[t]{2}{*}{ No } & \multirow[t]{2}{*}{ Pernyataan } & \multicolumn{24}{|c|}{ Mahasiswa } \\
\hline & & A & B & $\bar{C}$ & D & $\mathbf{E}$ & $\mathbf{F}$ & $\mathbf{G}$ & $\mathbf{H}$ & $\bar{I}$ & $\overline{\mathbf{J}}$ & $\mathbf{K}$ & $\mathbf{L}$ & $\bar{M}$ & $\mathbf{N}$ & $\mathbf{O}$ & $\mathbf{P}$ & $\overline{\mathbf{Q}}$ & $\mathbf{R}$ & $\mathrm{S}$ & $T$ & $\overline{\mathbf{U}}$ & $\bar{V}$ & $\mathbf{W}$ & $\bar{X}$ \\
\hline 1 & $\begin{array}{l}\text { Kejelasan rumusan } \\
\text { kompetensi dasar }\end{array}$ & 3 & 3 & 3 & 3 & 3 & 3 & 3 & 3 & 3 & 2 & 3 & 2 & 2 & 2 & 2 & 3 & 2 & 2 & 2 & 3 & 3 & 3 & 3 & 4 \\
\hline 2 & $\begin{array}{l}\text { Kejelasan rumusan } \\
\text { indikator keberhasilan }\end{array}$ & 2 & 2 & 2 & 3 & 3 & 3 & 3 & 3 & 3 & 2 & 3 & 2 & 2 & 2 & 2 & 3 & 2 & 2 & 2 & 3 & 3 & 3 & 3 & 4 \\
\hline 3 & $\begin{array}{l}\text { Kejelasan uraian materi } \\
\text { untuk dipelajari }\end{array}$ & 3 & 3 & 3 & 3 & 3 & 3 & 3 & 3 & 3 & 2 & 3 & 3 & 3 & 3 & 2 & 3 & 2 & 3 & 4 & 4 & 4 & 3 & 4 & 4 \\
\hline 4 & $\begin{array}{l}\text { Tayangan persiapan } \\
\text { peralatan Dodot } \\
\text { lengkap }\end{array}$ & 3 & 3 & 2 & 4 & 4 & 3 & 2 & 2 & 2 & 3 & 2 & 3 & 3 & 4 & 3 & 4 & 3 & 3 & 3 & 3 & 2 & 3 & 4 & 4 \\
\hline 5 & $\begin{array}{l}\text { Tayangan tahapan } \\
\text { mengenakan Dodot urut } \\
\text { dan runtut }\end{array}$ & 4 & 4 & 2 & 3 & 3 & 2 & 3 & 3 & 3 & 3 & 3 & 3 & 2 & 3 & 3 & 4 & 3 & 3 & 3 & 3 & 3 & 3 & 3 & 4 \\
\hline
\end{tabular}




\begin{tabular}{|c|c|c|c|c|c|c|c|c|c|c|c|c|c|c|c|c|c|c|c|c|c|c|c|c|c|}
\hline \multirow[t]{2}{*}{ No } & \multirow[t]{2}{*}{ Pernyataan } & \multicolumn{24}{|c|}{ Mahasiswa } \\
\hline & & $\bar{A}$ & B & $\bar{C}$ & $\bar{D}$ & $\bar{E}$ & $\bar{F}$ & $\bar{G}$ & $\mathbf{H}$ & $\bar{I}$ & $\overline{\mathbf{J}}$ & $\bar{K}$ & $\mathbf{L}$ & $\bar{M}$ & $\mathbf{N}$ & $\mathbf{O}$ & $\overline{\mathbf{P}}$ & $\bar{Q}$ & $\overline{\mathbf{R}}$ & $\mathrm{S}$ & $\bar{T}$ & $\overline{\mathbf{U}}$ & $\bar{V}$ & $\bar{W}$ & $\bar{X}$ \\
\hline 6 & $\begin{array}{l}\text { Penjelasan tahapan } \\
\text { mengenakan Dodot } \\
\text { mudah dimengerti }\end{array}$ & 4 & 4 & 2 & 3 & 3 & 3 & 3 & 3 & 3 & 3 & 2 & 3 & 2 & 3 & 3 & 2 & 2 & 3 & 3 & 3 & 2 & 3 & 3 & 4 \\
\hline 7 & $\begin{array}{l}\text { Proses mengenakan } \\
\text { dodot mudah diikuti }\end{array}$ & 4 & 4 & 2 & 3 & 3 & 3 & 2 & 2 & 2 & 3 & 3 & 3 & 2 & 3 & 3 & 4 & 3 & 3 & 3 & 3 & 4 & 3 & 3 & 3 \\
\hline 8 & $\begin{array}{l}\text { Penggunaan teks \& } \\
\text { gaya bahasa untuk } \\
\text { mendukung pemahaman } \\
\text { materi. }\end{array}$ & 3 & 3 & 2 & 4 & 4 & 2 & 3 & 3 & 3 & 3 & 3 & 3 & 3 & 3 & 3 & 3 & 3 & 3 & 3 & 3 & 3 & 3 & 3 & 3 \\
\hline 9 & $\begin{array}{l}\text { Penggunaan narasi } \\
\text { untuk mendukung } \\
\text { pemahaman anda } \\
\text { terhadap materi. }\end{array}$ & 3 & 3 & 2 & 4 & 4 & 3 & 2 & 2 & 2 & 3 & 2 & 3 & 3 & 3 & 3 & 3 & 3 & 3 & 3 & 2 & 3 & 3 & 2 & 3 \\
\hline
\end{tabular}

Berdasarkan Tabel 7 di atas, hasil data yang diperoleh dari penilaian oleh mahasiswa pada aspek kemudahan produk untuk dipelajari isinya menunjukkan bahwa skala penilaian 4 muncul sebanyak 28, skala penilaian 3 sebanyak 138, skala penilaian 2 sebanyak 50, dan skala penilaian 1 tidak muncul. Penilaian ini menunjukkan bahwa skala penilaian 3 lebih sering tampak dari skala penilaian yang lain. Skala penilaian 3 menyatakan baik dan hal ini berarti bahwa produk video pembelajaran ini mudah dipelajari isinya, atau dengan kata lain kemudahan produk untuk dipelajari isinya dapat dikatakan baik. c. Data yang berkenaan dengan aspek audio

Aspek audio terdiri dari empat butir pernyataan. Skor penilaian yang diberikan oleh mahasiswa akan digunakan untuk menentukan apakah aspek audio pada video pembelajaran ini sangat baik, baik, cukup baik, atau kurang baik. Aspek-aspek yang dinilai meliputi kualitas suara, artikulasi narasi, ketepatan pemilihan backsound dan keserasian antara backsound dengan narasi. Hasil penilaian tersebut dapat dilihat pada tabel. 8 sebagai berikut:

Tabel 8

Skor Penilaian Aspek Audio

\begin{tabular}{|c|c|c|c|c|c|c|c|c|c|c|c|c|c|c|c|c|c|c|c|c|c|c|c|c|c|}
\hline \multirow[t]{2}{*}{ No } & \multirow[t]{2}{*}{ Pernyataan } & \multicolumn{24}{|c|}{ Responden } \\
\hline & & $\overline{\mathbf{A}}$ & $\overline{\mathbf{B}}$ & $\bar{C}$ & $\overline{\mathbf{D}}$ & $\bar{E}$ & $\bar{F}$ & $\bar{G}$ & $\mathbf{H}$ & $\mathbf{I}$ & $\mathbf{J}$ & $\bar{K}$ & $\mathbf{L}$ & $\mathbf{M}$ & $\mathbf{N}$ & $\mathbf{O}$ & $\overline{\mathbf{P}}$ & $\mathbf{Q}$ & $\overline{\mathbf{R}}$ & $\mathrm{S}$ & $T$ & $\overline{\mathrm{US}}$ & $\overline{\mathbf{V}}$ & $\mathbf{W}$ & $\bar{X}$ \\
\hline 1 & $\begin{array}{l}\text { Kualitas suara dalam } \\
\text { menjelaskan jelas dan } \\
\text { bersih }\end{array}$ & 1 & 1 & 3 & 2 & 3 & 2 & 3 & 3 & 1 & 3 & 3 & 3 & 2 & 3 & 2 & 3 & 2 & 33 & 3 & 22 & 2 & 3 & 3 & 3 \\
\hline 2 & $\begin{array}{l}\text { Artikulasi narasi jelas } \\
\text { dan mudah dipahami }\end{array}$ & 3 & 3 & 2 & 2 & 2 & 3 & 3 & 3 & 3 & 3 & 3 & 3 & 3 & 3 & 2 & 2 & 3 & 33 & 3 & 33 & 3 & 3 & 3 & 4 \\
\hline 3 & $\begin{array}{l}\text { Ketepatan pemilihan } \\
\text { musik latar } \\
\text { (backsound) }\end{array}$ & 4 & 4 & 2 & 4 & 4 & 3 & 3 & 3 & 3 & 3 & 3 & 3 & 4 & 3 & 3 & 3 & 3 & 33 & 3 & 43 & 3 & 3 & 3 & 4 \\
\hline 4 & $\begin{array}{l}\text { Keserasian } \\
\text { penggunaan musik } \\
\text { latar dan narasi yang } \\
\text { dibacakan }\end{array}$ & 3 & 3 & 2 & 3 & 3 & 3 & 3 & 3 & 3 & 3 & 3 & 3 & 3 & 3 & 3 & 3 & 3 & 33 & 3 & 23 & 3 & 3 & 3 & 3 \\
\hline
\end{tabular}

Berdasarkan Tabel8 di atas, hasil data yang diperoleh dari penilaian oleh mahasiswa pada aspek audio pada produk video pembelajaran menunjukkan bahwa skala penilaian 4 muncul sebanyak 8 , skala penilaian 3 sebanyak 70 , skala penilaian 2 sebanyak 15, dan skala penilaian 1 muncul sebanyak 3. Penilaian ini menunjukkan bahwa skala penilaian 3 lebih sering tampak dari skala penilaian yang lain. Skala penilaian 3 menyatakan baik dan hal ini berarti dari aspek audio pada produk video pembelajaran dapat dikatakan baik.

Data-data yang diperoleh dari hasil penilaian ahli materi, ahli media dan data hasil uji coba produk, selanjutnya diolah 
menggunakan Ms.Excel 2007 untuk menghitung nilai yang sering muncul (modus).

a. Analisis data ahli materi
Hasil validasi ahli materi meliputi dua aspek, yaitu aspek pembelajaran dan aspek isi atau cakupan materi. Berikut hasil analisis aspek pembelajaran dan aspek isi:

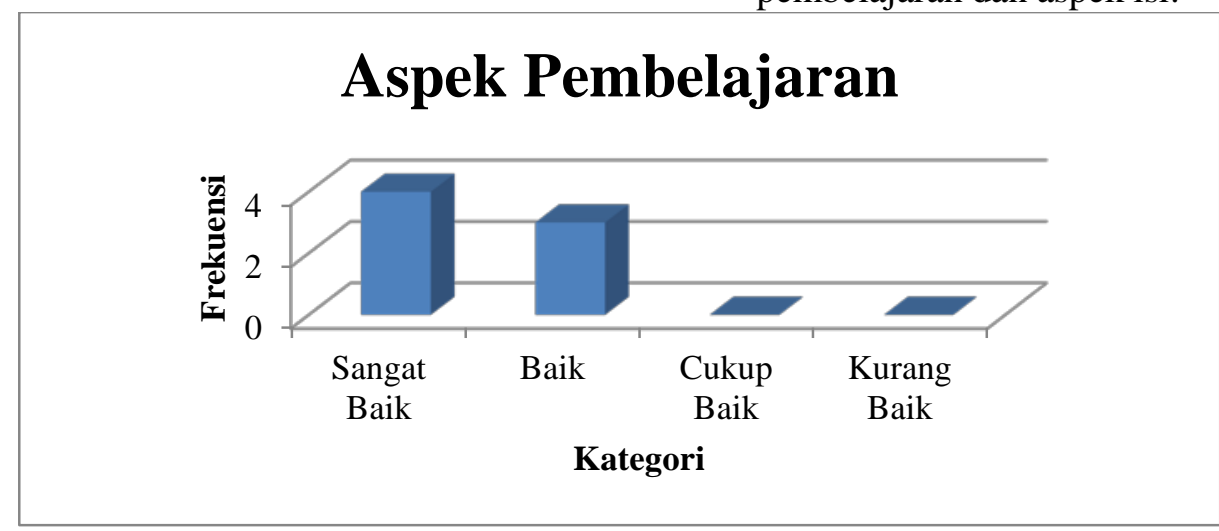

Gambar 1

Analisis data aspek pembelajaran oleh ahli materi

Berdasarkan data pada tabel 2 dari hasil validasi pembelajaran oleh ahli media diketahui bahwa modus skor penilaian adalah skala 4 sebanyak 4 dengan kategori Sangat
Baik sebesar 70 \%, skala 3 sebanyak 3 dengan kategori Baik sebesar 30 \%. Bila dilihat dari modus maka aspek pembelajaran dikategorikan Sangat Baik.

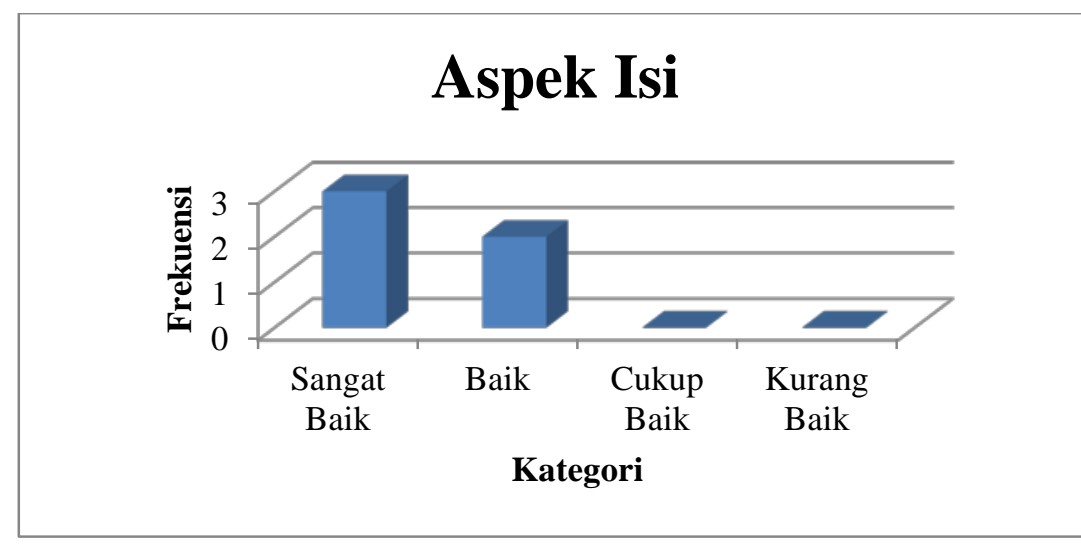

Gambar 2

Analisis data aspek pembelajaran oleh ahli materi

Berdasarkan data pada tabel 3 dari hasil validasi aspek isi/cakupan materi oleh ahli materi diketahui bahwa modus skor penilaian adalah skala 4 sebanyak 3 dengan kategori Sangat Baik sebesar 60 \%, skala 3 sebanyak 2 dengan kategori Baik sebesar $40 \%$. Bila dilihat dari modus maka aspek isi/cakupan materi dikategorikan Sangat Baik. b. Analisis data ahli media Aspek yang dinilai oleh ahli materi adalah pada aspek tampilan produk video pembelajaran Dodot Pengantin Putri Gaya Solo Basahan. Berikut hasil analisis data menggunakan Ms. Excel 2007, dengan menggunakan modus: 


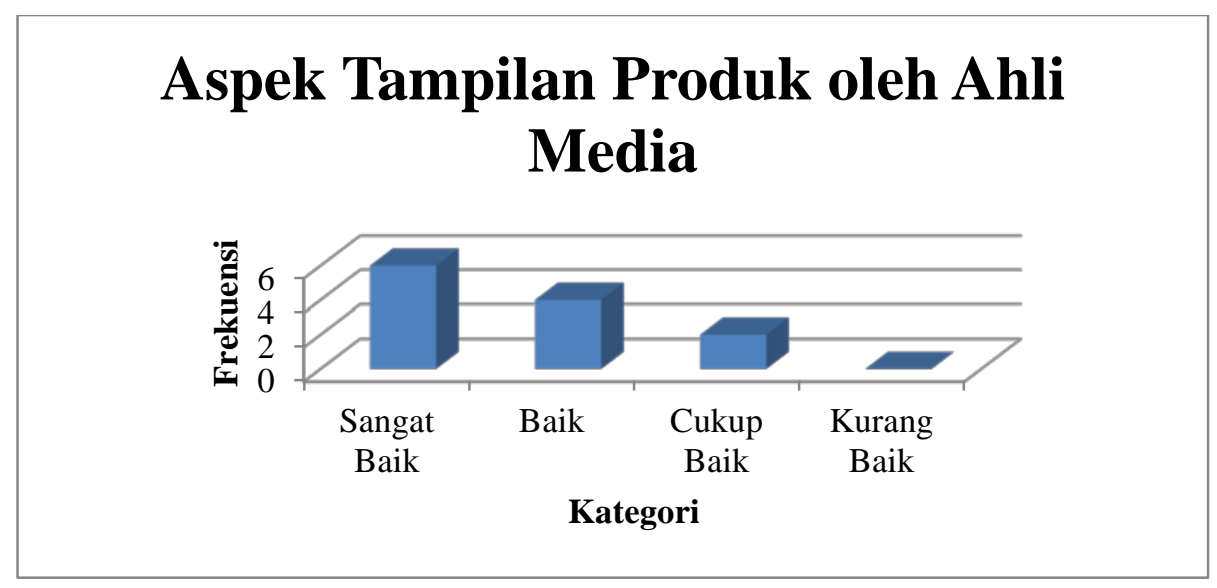

Gambar 3

Analisis data aspek pembelajaran oleh ahli materi

Berdasarkan data pada tabel 4 dari hasil validasi aspek tampilan produk oleh ahli media diketahui bahwa modus skor penilaian adalah skala 4 sebanyak 6 dengan kategori Sangat Baik sebesar $\mathbf{5 0} \%$, skala 3 sebanyak 4 dengan kategori Baik sebesar $33.33 \%$, skala 2 sebanyak 2 dengan kategori cukup baik sebesar 16,67 \%. Bila dilihat dari modus maka aspek tampilan produk oleh ahli media dikategorikan Sangat Baik.

c. Hasil analisis data aspek tampilan produk

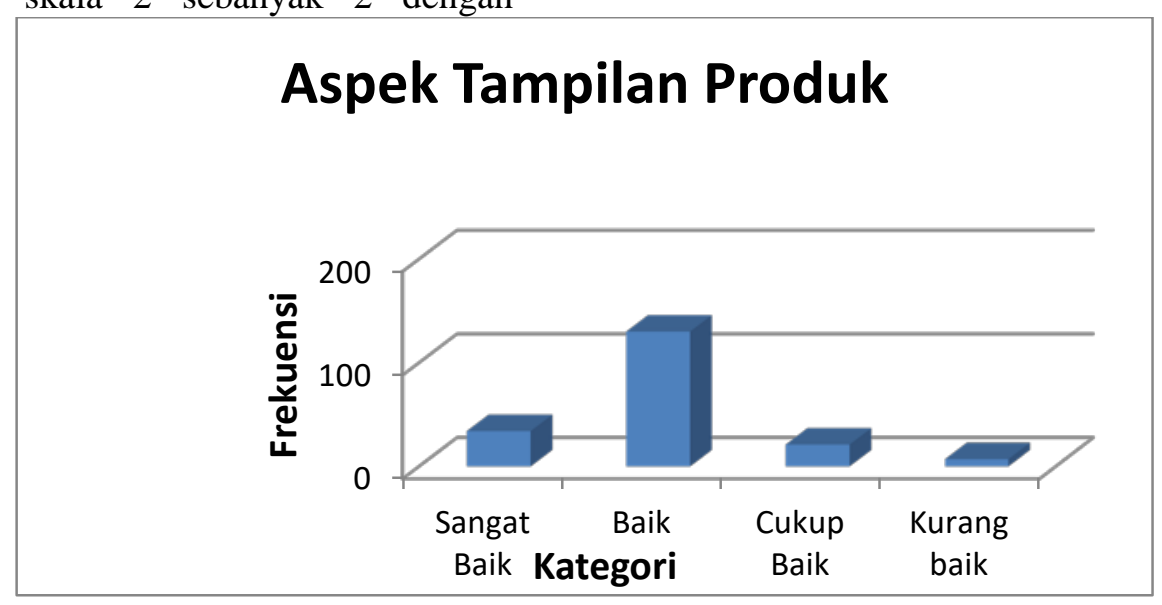

Gambar 4

Hasil análisis data aspek tampilan produk

Berdasarkan data pada tabel 5 dari hasil penilaian aspek tampilan produk diketahui bahwa modus skor penilaian adalah skala 4 sebanyak 34 dengan kategori Sangat Baik sebesar $17,70 \%$, skala 3 sebanyak 130 dengan kategori Baik sebesar 67,71 \%, skala 2 sebanyak 21 dengan kategori cukup baik sebesar 10,94 \%, dan skala 1 sebanyak 7 dengan kategori kurang baik sebesar 3,65 $\%$. Bila dilihat dari modus maka aspek tampilan produk dikategorikan Baik.

d. Analisis Aspek kemudahan produk untuk dipelajari isinya 


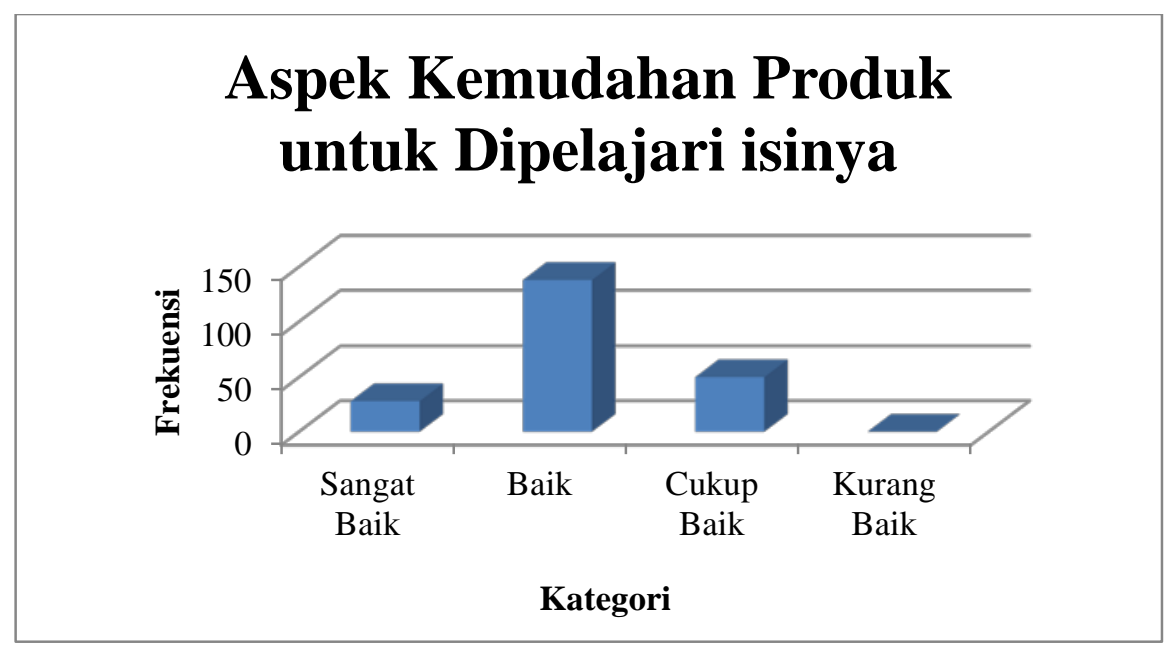

Gambar 5

Hasil análisis data aspek kemudahan produk untuk dipelajari isinya

Berdasarkan data pada tabel 6 dari hasil penilaian aspek kemudahan produk untuk dipelajari isinya, diketahui bahwa modus skor penilaian adalah skala 4 sebanyak 28 dengan kategori Sangat Baik sebesar 12,96 $\%$, skala 3 sebanyak 138 dengan kategori Baik sebesar 63,89 \%, skala 2 sebanyak 50 dengan kategori cukup baik sebesar 23,15
\%, dan skala 1 dengan kategori kurang baik tidak muncul. Bila dilihat dari modus maka aspek kemudahan produk untuk dipelajari isinya dikategorikan Baik. Dengan demikian maka produk mudah untuk dipelajari isinya.

e. Aspek audio

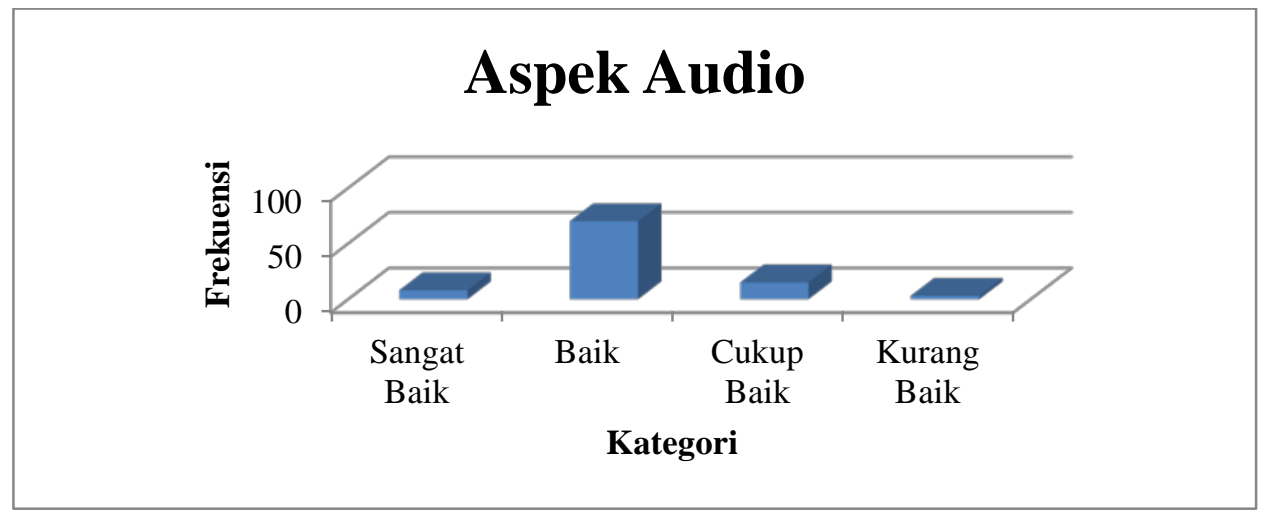

Gambar 6

Hasil análisis data aspek kemudahan produk untuk dipelajari isinya

Berdasarkan data pada tabel 7 dari hasil penilaian aspek audio, diketahui bahwa modus skor penilaian adalah skala 4 sebanyak 8 dengan kategori Sangat Baik sebesar 8,33\%, skala 3 sebanyak 70 dengan kategori Baik sebesar 72,92 \%, skala 2 sebanyak 15 dengan kategori cukup baik sebesar 15,63\%, dan skala 1 sebanyak 3 dengan kategori kurang baik sebanyak 3,12 $\%$. Bila dilihat dari modus maka aspek audio dikategorikan Baik

\section{SIMPULAN}

Berdasarkan hasil peneltian yang telah dilakukan dapat disimpulkan sebagai berikut:

1. Pengembangan Video Pembelajara Dodot pengantin gaya solo basahan terdiri dari beberapa tahapan antara lain: a)Terdapat perencanaan dalam merumuskan tujuan , disesuaikan dengan kebutuhan mahasiswa agar dapat tercapai kompetensi dibidang Tata Rias Pengantin.b) Pembuatan produk Video Pembelajara Dodot pengantin gaya solo basahan dengan prosedur yang 
direncanakan.c) Uji coba Video untuk memvalidasi produk, dengan validasi ahli materi,dan ahli media yang berkompeten di bidang Tata Rias Pengantin Terutama penganti Gaya Solo Basahan . d) Merevisi hasil produk dan memperbaiki sebelum dilakukan uji coba dilapangan.e) Uji coba produk dilapangan atau pada pengguna produk tersebut.f) membuat laporan hasil sesuai dengan data yang diperoleh dilapangan baik dari ahli materi, ahli media dan pengguna Video Dodot pengantin gaya solo basahan.

2. Hasil penelitian Video Pembelajaran Dodot Pengantin Putri Gaya Solo Basahan Puteri ini dalam kategori sangat layak sebagai sumber belajar menurut ahli media dan ahli materi, dan baik berdasarkan hasil uji coba di lapangan. Hasil penilaian ini menunjukkan bahwa Pengembangan Video Pembelajaran Dodot Pengantin Putri Gaya Solo Basahan yang dikembangkan dinilai layak digunakan sebagai sumber belajar.

\section{DAFTAR PUSTAKA}

Anik Ghufron.dkk(2007) Panduan Penelitian Pengembangan Bidang pendidikan dan Pembelajaran, Yogyakarta, Lemlit UNY

Arief Sadiman, (2002), Media Pendidikan, Pengertian, pengembangan dan Pemanfaatannya. Jakarta: Pt Raja Grafindo Persada.

Nanik Saryoto (2009), Tata Rias Pengantin Solo Basahan, Jakarta: Yayasan Insani Sugiyono (2006)

Yusuf hadi Miarso. (1986). Teknologi Pendidikan. Jakarta, CV. Rajawali. 